\title{
Combined central retinal artery and vein occlusion in lupus
}

\author{
Swapnil Madhukar Parchand, ${ }^{1}$ Vempuluru Sai Vijitha, ${ }^{2}$ Durga Prasanna Misra ${ }^{3}$
}

${ }^{1}$ Department of Ophthalmology, Jawaharlal Institute of Postgraduate Medical Education, Pondicherry, India ${ }^{2}$ Jawaharlal Institute of Postgraduate Medical Education, Pondicherry, India ${ }^{3}$ Department of Clinical Immunology, Jawaharlal Institute of Postgraduate Medical Education and Research, Pondicherry, India

\section{Correspondence to} Dr Swapnil Madhukar Parchand, swapnilp5656@ yahoo.co.in

Accepted 29 December 2016

CrossMark

To cite: Parchand SM, Vijitha VS, Misra DP. BMJ Case Rep Published online: [please include Day Month Year] doi:10.1136/bcr-2016218848

\section{DESCRIPTION}

A girl aged 16 years presented with sudden loss of vision in the left eye (LE) for 1 day. Visual acuity was $6 / 6$ in the right eye (RE) and perception of light in LE. LE had relative afferent pupillary defect. RE fundus had cotton wool spots (figure 1A). LE fundus showed combined central retinal artery occlusion (CRAO) and central retinal vein occlusion (CRVO) (figure 1B). Her history of alopecia, fever and arthritis for 6 months, bilateral cervical adenopathy, hard palate ulcers, leucopenia $\left(2300 / \mathrm{mm}^{3}\right)$, lymphopenia $\left(621 / \mathrm{mm}^{3}\right)$, positive antinuclear antibody and undetectable serum C4 led us to diagnose systemic lupus erythematosus (SLE). Lupus anticoagulant, anticardiolipin (IgM, $\operatorname{IgG})$ and anti- $\beta 2$ glycoprotein 1 (IgM, IgG) antibodies were negative. She was treated with highdose corticosteroids and anticoagulant therapy. On follow-up, she was also started on immunosuppressive agent methotrexate as a part of steroid-sparing therapy. Two weeks later, she received intense

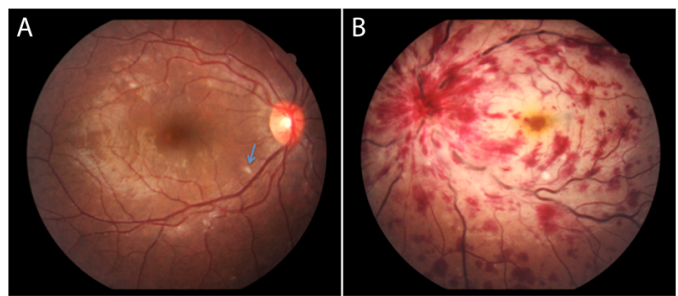

Figure 1 (A) Right eye fundus showing cotton wool spots (blue arrow). (B) Left eye fundus showing disc oedema, dilated and tortuously thrombosed retinal veins, arteriolar attenuation, extensive flame-shaped haemorrhages, retinal pallor and cherry-red spot at macula suggesting combined central retinal artery occlusion and central retinal vein occlusion. pan-retinal photocoagulation in LE to prevent neovascular glaucoma. Despite these efforts, she developed vitreous haemorrhage in LE on follow-up. Combined CRAO and CRVO though rare is a severe ocular complication of SLE resulting in irreversible loss of vision. Prompt diagnosis and early management in such a case is important to treat underlying systemic vasculitis and to prevent occurrence of similar episode in the other eye. ${ }^{12}$

\section{Learning points}

- Eye manifestation of systemic lupus erythematosus (SLE) may be sight threatening and can be an indicator of active disease.

- Spectrum of retinopathy in SLE varies from few isolated cotton wool spots to the severest form consisting of large retinal vascular occlusions.

Contributors SMP is responsible for managing the patient, idea, critical analysis and editing of manuscript. VSV is responsible for collection of data, writing and editing manuscript. DPM is responsible for managing the patient, editing and analysis of manuscript.

Competing interests None declared.

Patient consent Obtained.

Provenance and peer review Not commissioned; externally peer reviewed.

\section{REFERENCES}

1 Sivaraj RR, Durrani OM, Denniston AK, et al. Ocular manifestations of systemic lupus erythematosus. Rheumatology (Oxford) 2007;46:1757-62.

2 Chang PC, Chen WS, Lin HY, et al. Combined central retinal artery and vein occlusion in a patient with systemic lupus erythematosus and anti-phospholipid syndrome. Lupus 2010;19:206-9.

Copyright 2017 BMJ Publishing Group. All rights reserved. For permission to reuse any of this content visit

http://group.bmj.com/group/rights-licensing/permissions.

BMJ Case Report Fellows may re-use this article for personal use and teaching without any further permission.

Become a Fellow of BMJ Case Reports today and you can:

- Submit as many cases as you like

- Enjoy fast sympathetic peer review and rapid publication of accepted articles

- Access all the published articles

- Re-use any of the published material for personal use and teaching without further permission

For information on Institutional Fellowships contact consortiasales@bmjgroup.com

Visit casereports.bmj.com for more articles like this and to become a Fellow 